\title{
대장암에서 $\mathrm{RhoA}$ 의 발현과 임상적 의의
}

\author{
순천향대학교 의과대학 외과학교실, ${ }^{1}$ 내과학교실, ${ }^{2}$ 병리학교실
}

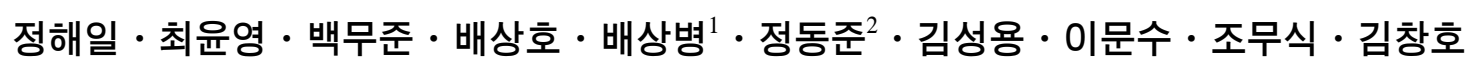

\section{Expression of RhoA in Colorectal Cancers and Its Clinicopathological Significance}

Hae II Jung, M.D., Yoon Young Choi, M.D., Moo Jun Baek, M.D., Sang Ho Bae, M.D., Sang Byung Bae, M.D. ${ }^{1}$, Dong Jun Jung, Ph.D. ${ }^{2}$, Sung Yong Kim, M.D., Moon Soo Lee, M.D., Moo Sik Cho, M.D., Chang Ho Kim, M.D.

Departments of Surgery, 'Medicine, ${ }^{2}$ Pathology, College of Medicine, Soonchunhyang University, Cheonan, Korea

Purpose: The Rho family of GTPases are involved in actin cytoskeleton organization and are associated with carcinogenesis and progression of human cancers. The clinicopathological significance of RhoA is not yet well known in the case of colorectal cancer. To investigate the expression of RhoA protein in colorectal carcinoma and to evaluate the relationship between RhoA protein expression and invasion and metastasis of colorectal cancer, we examined the expression of RhoA protein by using Western blotting and immunohistochemistry. Methods: The protein levels of RhoA in colorectal carcinomas of surgical specimens were analyzed in 7I consecutive patients with colorectal cancers by using immunohistochemistry and Western blotting. The relationships between the protein levels of RhoA in tumor tissues and the clinicopathological features of the patients were also assessed. Results: RhoA was highly expressed in 48 colorectal carcinomas (67.6\%). There was a significant association between RhoA expression and lymph nodal status. The expression of RhoA protein was related to lymph-node metastasis $(P=0.032)$ and advanced TNM tumor staging $(P=0.020)$. RhoA expression had a significant prognostic value for overall survival. Kaplan-Meier plots of survival in patients

접수: 2008년 8월 7일, 승인: 2008년 11월 19일

책임저자: 김창호, 330-721, 충남 천안시 봉명동 23-20

순천향대학교 천안병원 외과

Tel: 041-570-3631, Fax: 041-571-0129

E-mail: ssurge@sch.ac.kr

이 논문은 순천향대학교 대학 자체 학술 연구비의 지원으로 연 구되었음 with high RhoA showed that high RhoA expression was associated with a shorter overall survival. However, no association was found between RhoA and other pathologic or clinical variables, including age, gender, degree of differentiation, and presence of perineural spread. Conclusions: The RhoA protein may be related to malignant transformation and development of colorectal caricinomas and may play an important role in the invasion and the metastasis of colorectal carcinomas. J Korean Soc Coloproctol 2008;24:460-466

Keywords: Colorectal carcinoma, RhoA 대장암, RhoA

서 론

대장암은 전 세계적으로는 물론이려니와 우리나라 에서도 그 발생 빈도가 증가하는 추세에 있는 악성 종 양이다. 현재까지 대장암의 병인과 치료에 있어서도 활발한 연구가 있었으며, 특히 분자 생물학적인 발전 으로 대장암의 발생과정 및 전이의 유전자적 혹은 분 자생물학적인 기전에 대해 많은 연구가 이루어지고 있는 실정이다.

암의 진행과 전이의 과정 중에 암 세포는 여러 단계 의 세포 골격의 변화나 세포-세포, 혹은 세포-기질 유 착의 변화로 암 세포가 종양에서 분리되어 주변 조직 으로 침습하게 되며 원격 기관으로 전이하게 된다고 알려져 있다. ${ }^{1}$ 특히 전이가 암 세포의 탈부착의 일련의 과정이라고 본다면 최근까지 밝혀진 세포의 성장이나, 세포의 분화, 세포 골격의 구성과 관련된 여러 가지 신

Received August 7, 2008, Accepted November 19, 2008

Correspondence to: Chang Ho Kim, Department of Surgery, College of Medicine, Soonchunhyang University, 23-20, Bongmyeongdong, Cheonan 330-721, Korea

Tel: +82-41-570-3631, Fax: +82-41-571-0129

E-mail: ssurge @sch.ac.kr 
호 전달에 관여하는 Rho family small GTP binding 단백 질이 중요한 역할을 할 것임을 추정할 수 있겠다. ${ }^{2}$

Rho 단백은 Ras의 homologous (Rho)로 small GTP binding의 저분자 $(24 \mathrm{kDa})$ 단백질의 한 subfamily이다. 이러한 Rho family는 Rho (A, B, C), Rac $(1,2), \operatorname{Cdc} 42$ (Cdc42Hs, G25K), Rho D, RhoG, RhoE, TC10 등으로 구성되어 있다. Rho 단백질은 활성형의 GTP 결합형과 불활성형인 GDP 결합 사이를 순환하면서 분자적인 스위치로 작용하여 세포 내 하류 효과기(downstream effector)와 결합하여 액틴 중합과 유전자 발현 조절과 같은 다양한 세포 내 기능에 관여한다. ${ }^{3}$

특히, RhoA는 stress 섬유의 형성과 세포의 국소적인 유착을 조절하며, Rac1은 lamellipodia의 형성과 세포막 의 파상 운동을 조절하고, $\mathrm{Cdc} 42$ 는 filopodia의 형성을 조절한다. ${ }^{3}$ 이러한 RhoA, Rac1, $\mathrm{Cdc} 42$ 의 과발현은 여러 암종의 암화 과정과 연관이 있음이 보고되어 왔다.,5 $\mathrm{RhoA}$ 의 가장 특징적인 하류 효과기(downstream effector) 인 ROCK (Rho-associated serine-threonine protein kinase) 는 Rho의 활성형 GTP결합 형태에 선택적으로 결합할 때 활성화 되며, 활성화된 ROCK는 stress 섬유의 형성을 촉진하고 국소적 접촉을 조합하므로써 액틴 세포골격에 상호 작용한다. ${ }^{6}$

암환자의 생존에 있어서 가장 위협적인 것은 전이 이며, 암세포의 이동이 전이의 과정에서 중추적인 역 할을 한다. 따라서 Rho에 반응하여 액틴 세포 골격이 재편성되는 과정은 암세포의 전이 능력에 있어서 매 우 중요하다고 할 수 있을 것이다. ${ }^{7}$

이에 본 연구에서는 세포 골격 변화 및 운동성에 관 여하는 유전자로 알려진 RhoA 단백의 발현 여부를 다 섯 가지의 대장암 세포주 및 정상 대장 조직과 대장암 조직에서 살펴보고 RhoA 단백질의 발현과 실제 대장 암 환자의 여러 임상병리학적인 인자들과의 관련성 및 예후에 미치는 영향에 대해 알아보고자 하였다.

\section{방 법}

\section{1) 대상 환자}

2002년 1월부터 2003년 12월까지 순천향대학교 천 안병원 외과에서 결장 및 직장암으로 진단받고 수술 을 시행받은 후 경과 추적이 가능하였던 71 명의 환자 를 대상으로 후향적 분석을 시행하였다. 대상 환자의 나이, 성별, 병기 및 원격전이 유무를 조사하고, 병리 조직 보고서에서 분화 정도, 원발 암의 침윤의 깊이 및 림프절 전이 유무를 조사하였다.

\section{2) 대장암 세포주 및 정상 대장 조직과 대장암 조 직 보관}

연구 수행을 위해 수술 후 정상 대장 조직과 대장암 조직을 대장암 환자의 조직에서 분리하여 즉시 액화 질소로 냉각시킨 후 실험을 진행할 때까지 영하 $80^{\circ} \mathrm{C}$ 에서 저장하였다. 실험에 사용한 대장암 세포주는 SW480, LoVo, DLD-1, HCT116, HT29, CaCO2로서 세 포주는 한국 세포주 은행에서 구입하여 실험에 사용 할 때까지 동일한 조건하에 보관하였다.

\section{3) Western blot}

RhoA 단백질의 발현 여부를 알아보기 위해 여섯 가지 종류의 대장암 세포주에서 단백질을 추출하여 Western blot을 시행하였으며, 정상 대장 조직과 2병기 및 3 병기 환자의 대장암 조직에서 단백질을 추출하여 역시 Western blot을 시행하였다. 실험 방법은 세포주의 경우는 각각의 세포주에서 단백질을 추출하였으며 조직의 경우는 조직 을 homogenizer로 균일하게 분쇄한 후 lysis 용액인 Pro-PREPTM Protein Extraction solution (Intron, Korea)으 로 $-20^{\circ} \mathrm{C}$ 냉동고에서 cell lysis를 획득한 후 5 분간 $4^{\circ} \mathrm{C}$ $14,000 \mathrm{rpm}$ 에서 원심 분리하여 단백 추출을 얻었다. Bradford assay법으로 단백 농도를 측정하고 8 분간 가열 하여 변성(denaturation)시킨 후 $40 \mathrm{mg}$ 의 단백질을 $14 \%$ SDS-PAGE gel로 전기 영동하여 nitrocellulose 막에 전이 시켰다. Blot을 blocking buffer (4\% nonfat milk, $20 \mathrm{mM}$ Tris pH 7.5, $500 \mathrm{mM} \mathrm{NaCl}, 0.1 \%$ Tween 20)에서 1시간 배양한 후 일차 항체로 RhoA-specific antibody (Santa Cruz, USA)를 blocking buffer에 $1: 2,000$ 희석하여 $4^{\circ} \mathrm{C}$ 에 서 overnight하였다. 10분씩 3회 세척한 후 Anti-rabbit Ig, Horseradish peroxidase-linked whole antibody (form donkey) (Amersham) $1: 2,000$ 로 희석된 blocking buffer로 2 차 항체반응을 1 시간 반응 후 역시 3 회 세척한 후 $\mathrm{ECL}$ plus kit (Amersham)로 검출하여 반응을 확인하였다.

\section{4) 면역화학염색}

파라핀 포매된 조직 절편을 $4 \mu \mathrm{m}$ 두께로 박절한 후 조직 슬라이드를 항원의 재활성을 위해, $1 \mathrm{mM}$ EDTA 와 압력가열기에서 5 분간 가열하여 파라핀을 제거하 고, 내인성 peroxidase를 제거하기 위하여 $3 \%$ 과산화수 소 $\left(3 \% \mathrm{H}_{2} \mathrm{O}_{2}\right)$ 에 30 분간 작용시킨 후 증류수로 함수시 켰다. 이후 30 분간 실온에서 항 RhoA 항체(Santa Cruz, $\mathrm{CA}, \mathrm{USA})$ 와 배양하였다. 면역염색을 위해 다클론 항 체인 anti RhoA antibody (diluted 1:400 in PBS; Santa 
Cruz biotechnology)를 이용하였다. 면역조직화학적 염 색은 표준 avidin-biotin-peroxidase kit (DAKO Hamburg, Germany)를 이용하였고, 항 rabbit 면역글로블린으로 적정하였다. 마지막으로 조직 절편을 2,4-diaminobenzidine과 hematoxylin으로 역 염색 하였다. 면역 염색에 대한 결과 해석은 암세포의 $10 \%$ 미만이 염색되었을 때를 음성, $10 \%$ 이상 $25 \%$ 미만의 종양 세포가 염색된 경우를 약 양성, $25 \%$ 이상의 종양 세포가 강하게 염색 된 경우를 강 양성으로 분류하여, 약 양성과 강 양성 모두를 양성으로 분류하여 분석하였다.

\section{5) 통계분석}

통계분석은 SPSS program을 이용하였다. RhoA의 면 역형광염색 발현 정도와 환자의 여러 임상병리학적 인자들과의 관계를 비교하였으며 정상 대장조직과 대 장암 조직에서의 RhoA 단백질의 발현을 비교 분석하 였다. 각 그룹 간의 데이터를 비교하기 위하여 Chisquare test를 이용하였고, 생존율 분석을 위해 KaplanMeier 분석을 이용하였다. 생존 기간은 수술일로부터 생존 시에는 마지막 추적일까지로, 사망 시는 사망일 까지 하였으며 중앙 추적기간은 49개월이었다. 생존율 에 있어서 차이점의 의의 분석에는 Mantel-Cox-rank test를 이용하였다. 모든 통계적 분석은 양측 검정을 이 용하였으며, $\mathrm{P}<0.05$ 인 경우를 통계적인 유의성이 있 는 것으로 판정하였다.

\section{결 과}

대장암 환자 71 예의 평균 연령은 62.5 세였으며 남자 가 30명, 여자가 41명으로 남녀 비는 $1: 1.4$ 였다(Table 1). 암세포의 분화도에 따른 분류로는 고분화암이 9예 $(12.7 \%)$, 중등도 분화암이 58 예 $(81.7 \%)$, 저분화암이 4 예(5.6\%)이었다. 병기별 분류로는 병기 I기가 2예 $(2.8 \%), \mathrm{II}$ 기가 38 예(53.5\%), III기가 26예(36.6\%), IV기 가 5 예(7.1\%)이었다(Table 1).

기본적으로 대장암에서 $\mathrm{RhoA}$ 의 단백질이 발현되는 지를 알아보기 위해 여섯 종류의 대장암 세포주 (SW480, LoVo, DLD-1, HCT116, HT29, CaCO2)에서 단 백질을 추출하여 Western blot을 시행하였는데, 모든 대장암 세포주에서 RhoA 단백질이 발현되는 것을 관 찰할 수 있었으며(Fig. 1), 이는 세포주의 전이성 여부 와는 관련이 없었다. 대장암 환자의 정상 대장 점막과 2 병기 및 3 병기 환자의 대장암 조직을 이용하여 Western

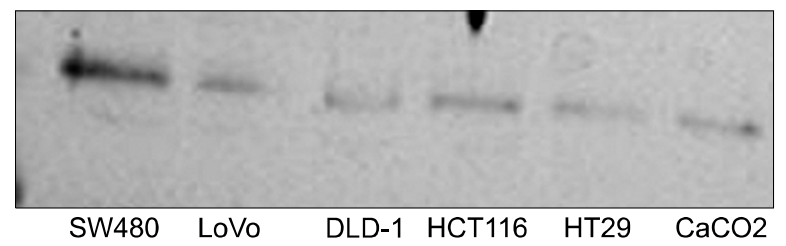

Fig. 1. RhoA expression in colon cancer cell lines.

Table 1. Clinicopathological data of patients and tumors according to RhoA expression

\begin{tabular}{|c|c|c|c|c|c|}
\hline & \multicolumn{2}{|c|}{ Patients } & \multicolumn{3}{|c|}{ RhoA Expression } \\
\hline & No. & $\%$ & Positive & $\%$ & P-value \\
\hline Total & 71 & & 48 & & \\
\hline Male & 30 & 42.3 & 28 & 93.3 & 0.088 \\
\hline Female & 41 & 57.7 & 20 & 48.8 & \\
\hline \multicolumn{6}{|l|}{ Age (years) } \\
\hline Median & 61.6 & & & & 0.480 \\
\hline Range & $26 \sim 85$ & & & & \\
\hline \multicolumn{6}{|c|}{ Lymph-node metastasis } \\
\hline Node negative & 40 & 55.7 & 19 & 47.5 & 0.032 \\
\hline Node positive & 31 & 44.3 & 29 & 93.5 & \\
\hline \multicolumn{6}{|l|}{ Grading } \\
\hline Well & 9 & 12.7 & 2 & & 0.725 \\
\hline Moderate & 58 & 81.7 & 22 & & \\
\hline Poor & 4 & 5.6 & 4 & & \\
\hline \multicolumn{6}{|l|}{ Stage } \\
\hline I & 2 & 2.8 & 19 & 0 & 0.020 \\
\hline II & 38 & 53.5 & 24 & 50.0 & \\
\hline III & 26 & 36.6 & 5 & 92.3 & \\
\hline IV & 5 & 7.1 & & 100 & \\
\hline
\end{tabular}


blot을 시행한 결과 전반적으로 정상 대장 점막보다 대 장암 조직에서 RhoA가 더 높게 발현됨을 관찰할 수 있었다(Fig. 2).

파라핀 포매된 대장암 조직을 이용하여 RhoA의 면 역형광염색을 시행한 결과(Fig. 3), 전체 71명의 대상 환자 중 48 예에서 RhoA가 발현되어 $67.6 \%$ 의 발현율을 나타내었다(Table 1). 림프절 전이가 없는 40예의 환자 중에서는 19예(47.5\%)에서 RhoA가 높게 발현되었으 며, 림프절 전이가 있었던 환자 31예 중에서는 29예 (93.5\%)에서 RhoA가 높게 발현되어 종양의 림프절 전 이가 있는 군에서 RhoA가 더 많이 발현됨을 관찰하였 다(P=0.032). 또한 TNM 병기에 따른 발현을 비교한 결

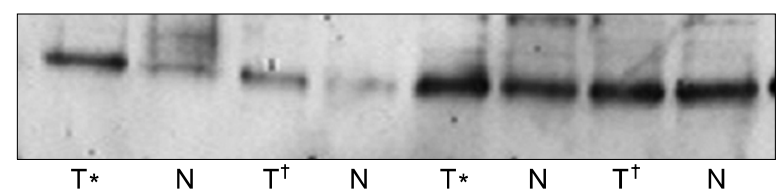

Fig. 2. Expression of RhoA in malignant and non-malignant tissues from the colon. $\mathrm{T}$ : colon cancer tissues; $\mathrm{N}$ : normal colon tissues. *: stage II colon cancer tissues; ${ }^{\dagger}$ : stage III colon cancer tissues.
과 RhoA의 발현은 병기가 진행될수록 RhoA가 더 발 현됨을 보여 주었다 $(\mathrm{P}=0.020)$. 하지만 $\mathrm{RhoA}$ 의 발현과 환자의 나이나 성별에 따른 차이는 발견할 수 없었으 며, 암 세포의 조직학적 분화도와도 차이가 없었다. Kaplan-Meier법을 이용하여 RhoA 발현 유무와 환자의 전체 생존율을 비교하였는데, RhoA가 발현된 환자에

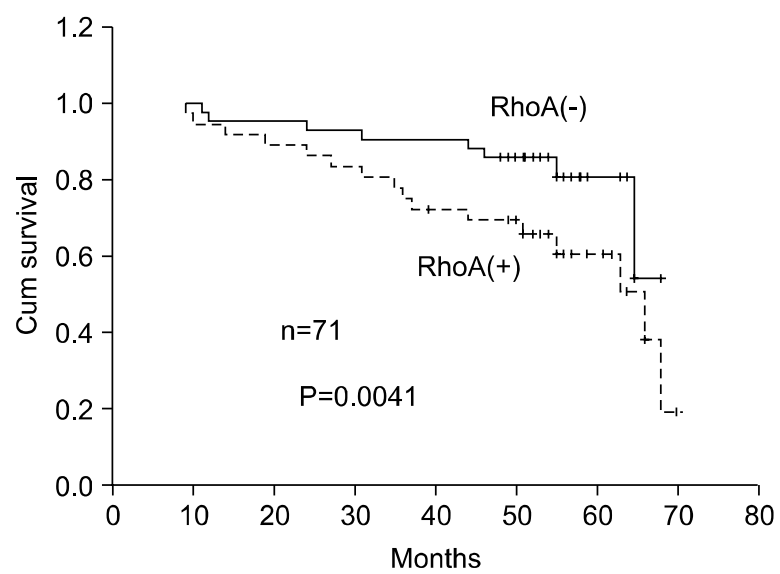

Fig. 4. Kaplan-Meier survival curves (log rank test) for negative and positive RhoA expression in cases of colorectal cancer.
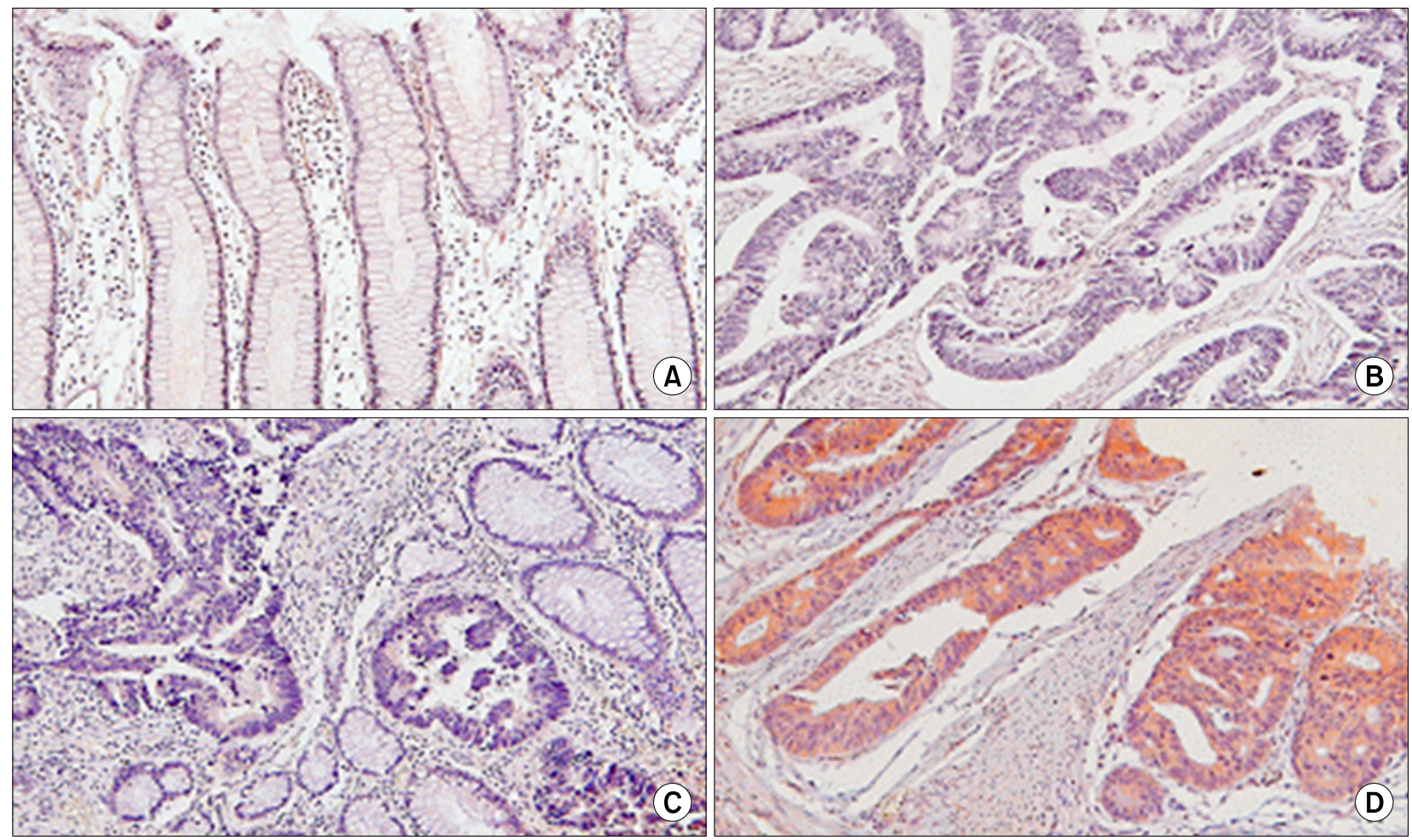

Fig. 3. Immunohistochemical stain of RhoA in normal colonic mucosa and colorectal cancer tissues. (A) RhoA negative normal colon tissue, (B) RhoA negative colon cancer tissue, (C) Mild RhoA positive colon cancer, and (D) Strong RhoA positive colon cancer, $\times 400$. 
서 발현되지 않았던 환자보다 더 나쁜 생존율을 보여, $\mathrm{RhoA}$ 의 발현이 환자의 예후와 관련이 있음을 나타내 주었다( $\mathrm{P}=0.0041)$ (Fig. 4).

\section{고 찰}

이번 연구에서는 RhoA의 발현이 대장암의 진행 및 전이에 미치는 영향을 알아보기 위해 RhoA의 발현 에 대해 Western blot과 면역형광염색검사를 시행하 여 대장암 환자의 임상병리학적인 여러 인자와의 관 계에 대해 알아봄과 동시에 RhoA 단백질의 발현이 대장암 환자의 예후에 미치는 영향에 관한 연구를 진행하였다.

저자들의 연구 결과 RhoA 단백질의 발현은 대장암 의 병기가 진행될수록, 그리고 대장암의 림프절 전이 가 있는 환자에서 더욱 발현이 증가됨을 확인할 수 있 었고 이는 대장암 환자의 예후와도 관계가 있음이 밝 혀졌다.

암 유전자와 암 억제 유전자의 과발현이나 활성화 또는 불활성화가 인간의 종양 형성과 관련이 있으며 이들 유전자들이 예후 인자로 사용될 수 있다는 사 실은 잘 알려져 있다. ${ }^{8}$ 이 중 Ras는 Rho와 같은 small GTPase로서 유전자의 점 돌연변이(point mutation)나 증폭(amplification)이 여러 종류의 종양에서 발견되었 다. 또 이 유전자는 인체 악성 종양에서 변이 빈도가 높고, 활성형일 경우 세포의 증식과 암세포의 증식을 가져온다고 알려져 있다. ${ }^{8}$ 하지만 많은 조사와 연구 에도 불구하고 아직 Rho 유전자의 경우에는 인체 악 성 종양에서 변이가 발생한다는 증거는 없다. ${ }^{9}$ 그러 나 이들 단백질을 GDP결합상태에서 GTP결합 상태 로 바꾸는 교환 단백질의 변이가 암의 발생에 관여 한다는 사실이 알려진 바가 있어 이는 Rho 신호 전 달 경로가 암의 발생에 중요한 역할을 할 것을 시사 한다고 보여진다. ${ }^{10}$

암이 좀 더 침습적이고 공격적인 표현형으로 진행 하는 동안 종양 세포는 세포-세포간 또는 세포 기질간 의 변화와 세포 골격의 재배열 등의 변화를 겪게 되어 종양 세포가 종양으로부터 떨어져 나와서 주위 조직 을 침습하며 결국 원격 기관으로의 전이를 일으키게 된다. ${ }^{1}$ 이 때 일어나는 변화 중 액틴 세포 골격의 재배 열은 일차적으로 RhoA, Rac1 그리고 $\mathrm{Cdc} 42$ 와 같은 Rho small GTPase 군의 일원에 의해 조절된다. ${ }^{11}$ 이러 한 Rho 단백질은 Rho $(\mathrm{A}, \mathrm{B}, \mathrm{C}), \operatorname{Rac}(1,2), \mathrm{Cdc} 42$ (Cdc42Hs, G25K), RhoD, RhoG, RhoE, TC10으로 구성
되어 있다. 이 중 RhoA의 주요 기능은 세포 골격의 재 구성을 조절하는 것으로, 다른 small GTPase와 같이 Rho GTPases도 비활성의 GDP결합 형태와 활성형의 GTP결합 형태를 순환한다. 이리하여 Rho 단백질은 세 포 외 자극을 액틴 세포골격과 핵으로 전달하는 세포 내에서 분자 스위치의 역할을 하면서 세포의 이동과 악성세포로의 전환을 조절하게 되는 것이다.

정상 mouse의 섬유모세포에서 RhoA의 과발현은 전 이의 성질을 유도하며, ${ }^{7}$ 이는 종양의 침습과 ${ }^{12}$ 파종에 관여하는 것으로 ${ }^{13}$ 알려져 있다. 또한 최근 연구 결과 에 따르면 RhoA 단백질은 마이오신(myosin)의 인산화 에 간접적으로 관여하여 이를 통해 국소적 유착 및 stress성 섬유근을 형성하는 것으로 보인다. ${ }^{14}$ 또한 마 이오신 사슬의 연장 및 액틴 섬유의 재배열, 유전자의 발현, 세포 골격의 형성, 세포 주기 진행의 조절에 직 접적으로 연관이 있다. ${ }^{10,14}$

Palazzo 등 ${ }^{15}$ 은 integrin-FAK 신호전달 경로에 의해 Rho 단백질이 그의 효과기(effector)를 활성화 시킨다고 하였는데, 이는 RhoA 단백질의 암화 과정에 관여하는 기전이 세포의 모양 및 운동성의 변화에 의한 것뿐만 아니라 세포와 세포 주위 기질의 상호 작용에 의한 것 임을 보여준다. RhoA 단백질과 그의 효과기인 ROCK 의 활성화는 integrin이 focal adhesion에 관여하는 데 필 요하다. ${ }^{16}$

또한 Rho 단백질은 세포외 기질을 파괴할 수 있는 matrix metalloproteinase (MMP)나 그의 길항제인 tissue inhibitors of metalloproteinase (TIMPs)의 수준을 조절함 으로서 세포외 기질의 파괴나 재형성을 조절할 수 있 다. ${ }^{17}$ 이와 같은 기전에 의한 세포외 기질의 $\mathrm{MMP}$ 와 TIMP 활성도의 불균형은 기질의 과도한 파괴를 초래 하고 이는 종양의 침습과 전이에 특징적인 소견이 다. ${ }^{18,19}$

Rho가 종양의 발생과 진행 과정에서 암 세포의 이 동성, 침습성 그리고 전이성 표현형을 얻는 데 있어 서 직접적인 역할을 하는 것이 알려져 있으며, ${ }^{7,20}$ 종 양 세포가 전이되는 데 있어서도 중요한 것으로 생 각되고 있다.

높은 Rho의 발현은 이 단백질이 세포질(cytosol)에서 세포막으로 전위(translocation)되는 것을 용이하게 하 며 그 곳에서 활성화되어 침습을 촉진하게 된다. ${ }^{21}$ 이 러한 기전으로 Rho 발현의 증가는 인간의 여러 암종에 서 진행된 병기와 관련이 있다는 여러 연구 결과들이 보고되었다. ${ }^{5,22,23}$

이러한 사실을 바탕으로 최근까지 발암기전에 있어 
RhoA의 역할에 대한 많은 조사가 이루어지고 있고 유 방, 간, 췌장, 난소, 방광, 고환 생식세포 종양, 두경부 상피세포 종양 등, 다양한 종양 조직에서 $\mathrm{RhoA}$ 의 과발 현이 연구 발표되어 왔다., ${ }^{422-25}$

본 연구에서는 RhoA의 발현이 대장암의 악성도, 다 시 말해 림프절 전이 및 병기의 진행과 관련이 있는 것으로 밝혀졌다. 이 연구 결과에 의해 RhoA는 대장암 의 암화 과정, 특히 종양 세포의 이동에 있어 매우 중 요한 역할을 할 것으로 생각하며, 이 물질을 표적으로 하는 치료법의 개발이 대장암 치료의 중요한 전환점 이 될 수도 있을 것으로 생각한다.

조기 대장암인 경우 수술만으로도 생존율 향상을 기대할 수 있지만 암이 전이된 환자이거나 림프절 전 이가 있어 암의 재발 또는 전이 가능성이 높은 환자에 게는 추가적인 치료가 필요하다. 많은 진단적 기술이 발전했지만 아직까지도 대장암의 림프절 전이에 대해 정확한 진단이 어려운 상태이다. ${ }^{26,27}$ 따라서 $\mathrm{RhoA}$ 의 활동성을 측정하는 것이 대장암의 림프절 전이 가능 성 및 향후 치료에 있어 유용한 표적 인자가 될 수 있 다. 하지만 $\mathrm{RhoA}$ 의 발현을 증가시키는 가장 중요한 인 자가 무엇이며 그 인자들의 측정은 어떻게 할 것인지 에 대한 문제는 앞으로 연구해야 할 부문이다.

\section{결 론}

대장암에서 여러 임상병리학적 요소와 RhoA 단백 질의 과발현이 연관이 있음이 관찰되고 정상 대장 조 직에 비해 대장암 조직에서 증가함이 관찰됨으로써, RhoA 단백질이 대장암의 발생과 진행과정에 중요한 역할을 할 것으로 생각하고 대장암의 향후 치료에 있 어 분자적인 표적이 될 수 있을 것으로 기대된다.

\section{REFERENCES}

1. Cavallaro U, Christofori G. Cell adhesion and signalling by cadherins and Ig-CAMs in cancer. Nat Rev Cancer 2004;4:118-32.

2. Hall A. Rho GTPases and the actin cytoskeleton. Science 1998;279:509-14.

3. Minden A, Lin A, Claret FX, Abo A, Karin M. Selective activation of the JNK signaling cascade and c-Jun transcriptional activity by the small GTPases Rac and Cdc42Hs. Cell 1995;81:1147-57.

4. Sahai E, Marshall CJ. Rho-GTPases and cancer. Nat Rev Cancer 2002;2:133-42.
5. Fritz G, Just I, Kaina B. Rho GTPases are over-expressed in human tumors. Int J Cancer 1999;81:682-7.

6. Ishizaki T, Naito M, Fujisawa K, Maekawa M, Watanabe $\mathrm{N}$, Saito Y, et al. p160ROCK, a Rho-associated coiled-coil forming protein kinase, works downstream of Rho and induces focal adhesions. FEBS Lett 1997;404:118-24.

7. del Peso L, Hernandez-Alcoceba R, Embade N, Carnero A, Esteve P, Paje C, et al. Rho proteins induce metastatic properties in vivo. Oncogene 1997;15:3047-57.

8. Bos JL. The ras gene family and human carcinogenesis. Mutat Res 1988;195:255-71.

9. Moscow JA, He R, Gnarra JR, Knutsen T, Weng Y, Zhao W, et al. Examination of human tumors for rhoA mutations. Oncogene 1994;9:189-94.

10. Zhang B, Zheng Y. Regulation of RhoA GTP hydrolysis by the GTPase-activating proteins p190, p50RhoGAP, Bcr, and 3BP-1. Biochemistry 1998;37:5249-57.

11. Burridge K, Wennerberg K. Rho and Rac take center stage. Cell 2004;116:167-79.

12. Ridley AJ. Rho GTPases and cell migration. J Cell Sci 2001;114:2713-22.

13. Vasiliev JM, Omelchenko T, Gelfand IM, Feder HH, Bonder EM. Rho overexpression leads to mitosisassociated detachment of cells from epithelial sheets: a link to the mechanism of cancer dissemination. Proc Natl Acad Sci U S A 2004;101:12526-30.

14. Fujita H, Katoh H, Hasegawa H, Yasui H, Aoki J, Yamaguchi Y, et al. Molecular decipherment of Rho effector pathways regulating tight-junction permeability. Biochem J 2000;346:617-22.

15. Palazzo AF, Eng CH, Schlaepfer DD, Marcantonio EE, Gundersen GG. Localized stabilization of microtubules by integrin- and FAK-facilitated Rho signaling. Science 2004;303:836-9.

16. Narumiya S, Ishizaki T, Watanabe N. Rho effectors and reorganization of actin cytoskeleton. FEBS lett 1997; 410:68-72.

17. Matsumoto $Y$, Tanaka K, Harimaya K, Nakatani F, Matsuda S, Iwamoto Y. Small GTP-binding protein, Rho, both increased and decreased cellular motility, activation of matrix metalloproteinase 2 and invasion of human osteosarcoma cells. Jpn J Cancer Res 2001;92:429-38.

18. Liotta LA, Steeg PS, Stetler-Stevenson WG. Cancer metastasis and angiogenesis: an imbalance of positive and negative regulation. Cell 1991;64:327-36.

19. Tanaka K, Iwamoto Y, Ito Y, Ishibashi T, Nakabeppu Y, Sekiguchi M, et al. Cyclic AMP-regulated synthesis of the tissue inhibitors of metalloproteinases suppresses the invasive potential of the human fibrosarcoma cell line HT1080. Cancer Res 1995;55:2927-35.

20. Schmitz, AA, Govek EE, Bottner B, Van Aelst L. Rho GTPases: signaling, migration, and invasion. Exp Cell 
Res 2000;261:1-12.

21. Yoshioka K, Nakamori S, Itoh K. Overexpression of samll GTP-binding protein RhoA promotes invasion of tumor cells. Cancer Res 1999;59:2004-10.

22. Kamai T, Arai K, Tsujii T, Honda M, Yoshida K. Overexpression of RhoA mRNA is associated with advanced stage in testicular germ cell tumour. BJU Int 2001;87:227-31.

23. Suwa $H$, Ohshio G, Imamura $T$, Watanabe $G$, Arii $S$, Imamura $\mathrm{M}$, et al. Overexpression of the rhoC gene correlates with progression of ductal adenocarcinoma of the pancreas. Br J Cancer 1998;77:147-52.

24. Wang W, Yang LY, Yang ZL, Huang GW, Lu WQ. Expression and significance of RhoC gene in hepatocellular carcinoma. World J Gastroenterol 2003;9:1950-3.

25. Horiuchi A, Imai T, Wang C, Ohira S, Feng Y, Nikaido $\mathrm{T}$, et al. Up-regulation of small GTPases, RhoA and RhoC, is associated with tumor progression in ovarian carcinoma. Lab Invest 2003;83:861-70.

26. McNicholas MM, Joyce WP, Dolan J, Gibney RG, MacErlaine DP, Hyland J. Magnetic resonance imaging of rectal carcinoma: a prospective study. Br J Surg 1994; 81:911-4.

27. Saitoh N, Okui K, Sarashina H, Suzuki M, Arai T, Nunomura M. Evaluation of echographic diagnosis of rectal cancer using intrarectal ultrasonic examination. Dis Colon Rectum 1986;29:234-42. 